【原著】

泌尿器科外来通院患者における補完代替医療利用実態の聞き 取り調査

Prevalence of Complementary and Alternative Medicine Use in Ambulatory Patients with Urologic Disorders

丸谷晃子 ${ }^{1}$ ，松木幸栄 ${ }^{1}$ ，八田理恵 ${ }^{1}$ ，斎藤佳恵 ${ }^{1}$ ，橋本多恵 ${ }^{1}$ ，水野一美 ${ }^{1}$ ，竹内弘美 ${ }^{1}$, 冨田静江 ${ }^{1}$ ，大野 智 ${ }^{2}$ ，小松和人 ${ }^{3}$ ，並木幹夫 ${ }^{3}$ Akiko MARUTANI ${ }^{1}$, Sachie MATUKI ${ }^{1}$, Rie HATTA ${ }^{1}$, Yoshie SAITO ${ }^{1}$, Tae HASHIMOTO ${ }^{1}$, Kazumi MIZUNO ${ }^{1}$, Hiromi TAKEUCHI ${ }^{1}$, Shizue TOMITA ${ }^{1}$, Satoshi OHNO ${ }^{2}$, Kazuto KOMATSU ${ }^{3}$, Mikio NAMIKI ${ }^{3}$

\author{
1 金沢大学医学部附属病院 \\ 2 金沢大学補完代替医療学講座 \\ 3 金沢大学泌尿器科学講座
}

【要 旨】

我が国における癌患者の補完代替医療利用の 実態についての報告は散見されるが，良性疾 患も含めた外来通院患者の利用実態について の報告は少ない，そこで，我々は，2004年3 月10〜31日までに金沢大学医学部附属病院 泌尿器科外来を受診した全患者331名を対象 に代替医療利用実態の聞き取り調査を行なっ た. 補完代替医療利用者は101名 (30.5\%) て あり，年齢，性別による利用率の差は認めな かった. 疾患別の利用率は良性疾患 55 名 (27.0\%)，悪性疾患46名（36.2\%）であり， 悪性疾患患者の利用率が高い傾向を認めた $(P=0.08)$. また, 利用者のうち医療従事者に 補完代替医療の利用を相談している患者は, 16名（15.8\%）であった.このことより我々 は補完代替医療の現状を十分把握していない ことが推測された. 補完代替医療を併用する 患者を把握し，患者に不利益がないか検証す ることが今後の課題であることが示唆され た.

【キーワード】

泌尿器科疾患, 補完代替医療, 看護
はじめに

補完代替医療 (complementary and alternative medicine, CAM) とは,「現代西洋医学に打いて科学的未検証及び臨

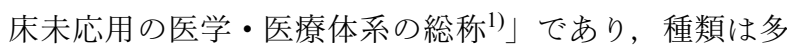
彩である。しかし，日本に打けるCAMは基本的概念が未 だ不明瞭2)であるとも言われている。

$\mathrm{CAM}$ の利用率に関する先行研究では，厚生労働省研 究班 ${ }^{3)}$ による, がん患者の自己記入式アンケート調査で, その利用率は $44.6 \%$ と高い結果を示している．また，健

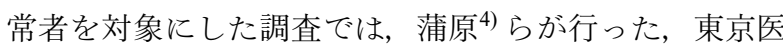
科大学の健康診断受診者 3123 例（有効回答率 37.2\%) を 対象にした自己記入式アンケート調査で $65.1 \%$ が利用し ているという報告がある，入院患者を対象にした調査で は山本ら5) の聖マリアンナ医科大学病院入院患者 271 例 (自由意志による参加者のみ)を対象に同じく自己記入式 アンケート調査があり， $72.4 \%$ と高い CAM 利用率を示 している.これより，病院で診療を受けている患者の CAM 利用率は高いと推測されるが，いずれも，アンケー トの回収率は，40-50\%3-6) であることから，より正確な 利用実態を知るためには，自己記入式アンケート調査の

受理日：2004 年 11 月 18 日

1=920-8641 石川県金沢市宝町 13-1 金沢大学医学部附属病院 
限界も指摘されている。

一方で，特定の診療科を対象にした報告は少なく，池 内2) は専門分野領域の各疾患ごとに CAM の実施状況を 正しく把握することが重要であると述べている. 泌尿器 科領域では, Diefenbach ら ${ }^{7)}$ は, 限局性前立腺癌患者 417 例の外来通院患者を対象にした郵送法による調査で，19 $\%$ の患者が病名告知後 CAM を利用して扣り，67\%が健 康時より CAM を利用していると報告している. 吉村ら ${ }^{8)}$ は, 177 例の前立腺癌患者の外来通院患者を対象にした 調査で，20\%の患者が CAM を利用していると報告して いる. しかし, がん以外の疾病も含めた泌尿器科医療現 場全体に打ける現状は必ずしも明らかではない。

我々は，金沢大学医学部附属病院泌尿器科外来通院患 者に打けるCAM 利用実態を明らかにするために, 全通 院患者を対象に聞き取り調査を行った，また，本研究は， 泌尿器科疾患を有する患者の CAM の利用状況を明らか にすることで, 看護師として患者との対応における今後 の課題を明らかにすることを目的とした.

\section{対象と方法}

\section{1. 対象}

2004 年 3 月 10 日から 3 月 31 日までに金沢大学医学部
附属病院泌尿器科外来を受診した全患者 331 名を対象と し，外来受診時に外来担当医より直接本人に対して過去 一年間の CAM 利用の有無について質問した. さらに, CAM 利用者に対しては，研究の趣旨に同意が得られた 患者を対象に, 看護師が質問紙による聞き取り調査を 行った.

\section{2. 調査方法}

厚生労働省研究班 3 ) と兵頭ら 9) の質問票を参考に質問票 を作成し, 聞き取り調査を行った。調査項目は, 患者の背 景, 就業状況, 家族構成, 診断病名, CAM 利用の有無, $\mathrm{CAM}$ の利用目的, CAM の費用，医療従事者への申告，医 療従事者に求める CAM の情報などを含む 21 項目である (表 1 ).

\section{3. 統計解析}

調査結果は, 統計ソフト Stat View 5.0 を用いて統計処 理を行った. 自由記述については, 研究者間で内容分析 を行った。

表 1 質問票の調査項目

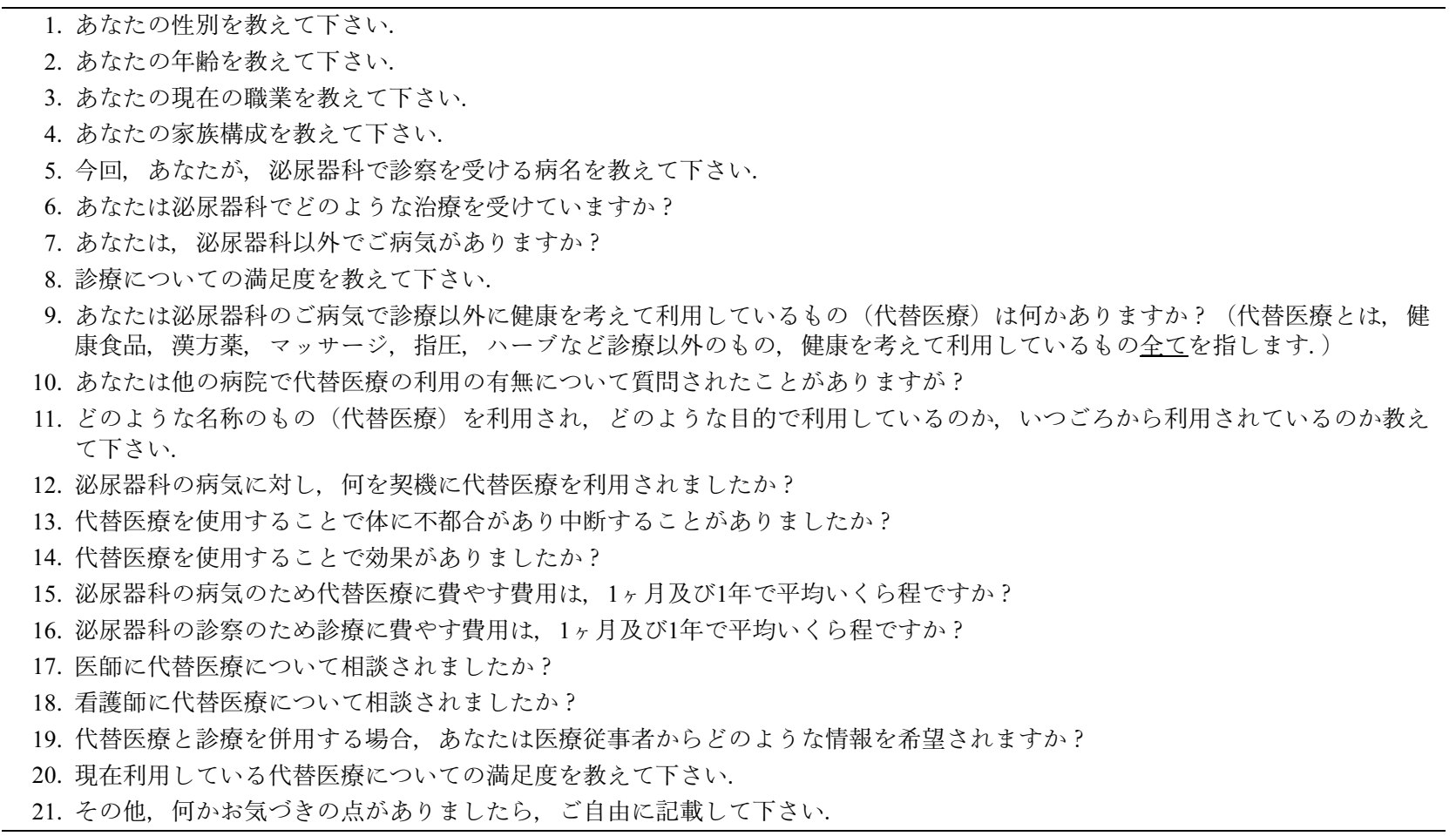




\section{4. 倫理的配慮}

対象者に文書を用いて研究の趣旨と方法, 得られた情報 の守秘, 研究途中の辞退が可能であること, 研究参加は自 由であり参加を希望しない場合でも治療や看護に影響し ないこと，公表する場合をプライバシーは保護されるなど 説明し, 書面で研究参加の同意署名を得た. なお本研究は, 当院看護部看護研究倫理委員会で承認を受けた。

\section{結 果}

\section{1. 患者背景}

2004 年 3 月 10 日から 3 月 31 日までに金沢大学医学部 附属病院泌尿器科外来を受診した 331 名の平均年齢は, 65.8 歳で, 男性 271 名, 女性 60 名であった。 そのらち, $\mathrm{CAM}$ 利用者は 101 名 $(30.5 \%)$ で, 複数利用者は 35 名 であった．年齢，性別，疾患の種類による CAM 利用の 頻度の違いに関して表 2 亿示す。その結果，CAMの利

表 2 対象者の背景 $(\mathrm{N}=331)$

\begin{tabular}{cccccc}
\hline 項目 & $\begin{array}{c}\text { 患者数 } \\
(\text { 名 })\end{array}$ & $\begin{array}{c}\mathrm{CAM} \text { 利用者 } \\
(\%)\end{array}$ & $\begin{array}{c}\mathrm{CAM} \text { 非利用者 } \\
(\%)\end{array}$ & $\chi^{2}$ 検定 \\
\hline 年齢 & & & & & \\
$\leq 65$ 歳 & 125 & $40(32.0 \%)$ & $85(68.0 \%)$ & \\
$>65$ 歳 & 206 & $61(29.6 \%)$ & $145(70.4 \%)$ & $\mathrm{P}=0.6473$ \\
性別 & & & & & \\
$\quad$ 男性 & 271 & $83(30.6 \%)$ & $188(69.4 \%)$ & \\
女性 & 61 & $18(30.0 \%)$ & $42(70.0 \%)$ & $\mathrm{P}=0.9239$ \\
診断 & & & & & \\
悪性 & 127 & $46(36.2 \%)$ & $81(63.8 \%)$ & \\
良性 & 204 & $55(27.0 \%)$ & $149(73.0 \%)$ & $\mathrm{P}=0.0752$ \\
\hline
\end{tabular}

用に関して, 良性疾患患者よりも悪性疾患患者のほうが, 利用率が高い傾向を示した $(\mathrm{P}=0.08)$. 年齢，性別の影響 は認めなかった。ささらに，詳細な年代別の CAM 利用率 を図 1 亿，疾患別の CAM 利用率を表 3 亿示す。

また，CAM 利用者の主な利用開始時期は，健康時 19 名, 症状発現時 21 名, 病気の疑い時 3 名, 病名告知時 16 名, 治療前 2 名, 治療中 3 名, 治療後 - 退院後 26 名, 不明 11 名であった。

\section{CAM の利用目的・内容・費用}

CAM 利用目的には，加齢に関連したもの，がんに関 連したもの，症状に関連したものが主であった。その内 訳は，加齢に関連したものでは，「健康維持」31 名なぞ であった．がんに関連したものでは，「がん再発予防」25 名,「免疫力向上」 16 名, 「治療の副作用予防」 6 名, 「PSA 低下を期待」5名などであった，症状に関連したもので は, 特に泌尿器科疾患とは関係なく西洋医学では改善し ない「症状（便秘，腰痛など）の改善」25 名，「排尿困

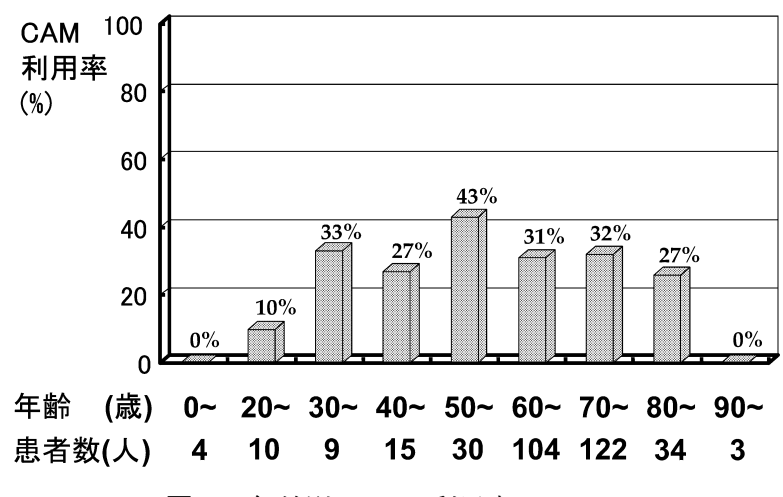

図 1 年齢別, $C A M$ 利用率 $(N=331)$

表 3 疾患別, CAM 利用率 $(\mathrm{N}=331)$

\begin{tabular}{|c|c|c|c|c|c|}
\hline \multicolumn{3}{|c|}{ 良性疾患 } & \multicolumn{3}{|c|}{ 悪性疾患 } \\
\hline 前立腺肥大症 & $22 / 78$ & $(28.2 \%)$ & 前立腺癌 & $27 / 75$ & $(33.3 \%)$ \\
\hline 神経因性膀胱 & $9 / 35$ & $(25.7 \%)$ & 膀胱癌 & $10 / 25$ & $(40.0 \%)$ \\
\hline 腎尿管結石症 & $5 / 16$ & $(31.2 \%)$ & 腎癌 & $5 / 15$ & $(41.6 \%)$ \\
\hline 尿失禁 & $2 / 15$ & $(13.3 \%)$ & 精巣腫瘍 & $3 / 8$ & $(37.5 \%)$ \\
\hline 血尿 & $3 / 10$ & $(30.0 \%)$ & 後腹膜腫瘍 & $1 / 1$ & $(100.0 \%)$ \\
\hline 男性不妊症 & $2 / 9$ & $(22.2 \%)$ & & & \\
\hline PSA高値 & $6 / 7$ & $(75.0 \%)$ & & & \\
\hline 膀胱炎 & $1 / 7$ & $(20.0 \%)$ & & & \\
\hline 性機能不全症 & $1 / 6$ & $(16.6 \%)$ & & & \\
\hline 水腎症 & $1 / 5$ & $(20.0 \%)$ & & & \\
\hline 二分脊椎症 & $1 / 3$ & $(33.3 \%)$ & & & \\
\hline 男性更年期障害 & $1 / 1$ & $(100.0 \%)$ & & & \\
\hline 尿道カルンケル & $1 / 1$ & $(100.0 \%)$ & & & \\
\hline
\end{tabular}




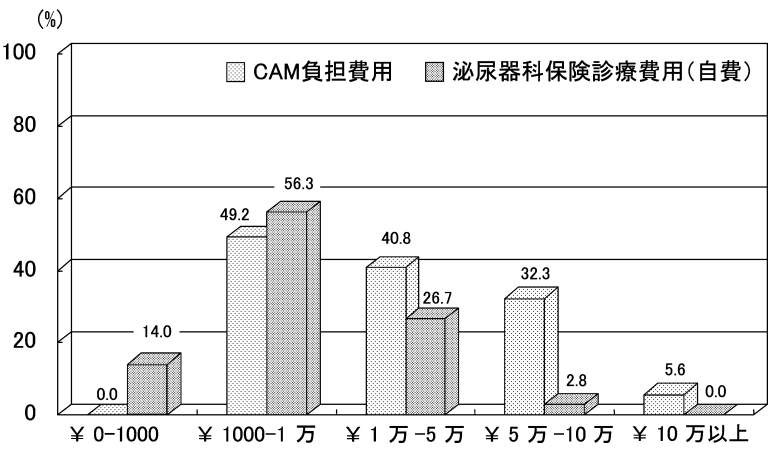

図 21 ヶ月あたりの CAM 利用費用 $(\mathrm{N}=90)$

難」4名,「精力増強」3 名などであった.

また，CAM の利用内容については，健康食品 71 名，ビ タミン凰 11 名, 漢方薬 10 名, はり 3 名, 指圧 2 名, 温 泉療法 1 名, マッサージ 1 名, 気功 1 名なぞであった.

さらに, 1 ヶ月の CAM 負担費用と泌尿器科保険受診療 費（自己負担分）は，打预よその費用を本人が把握でき ていた 90 名に関して集計した（図2）。そのうち，正確 な金額を把握していた 72 名(家族や友人から譲渡されて いるため正確な CAM 負担費用が不明であった対象者を 90 名から除いた人数), に関して統計解析をしたところ, CAM 負担費用の平均土標準偏差は, $¥ 21,302 \pm 30,286$ (median; ¥ 10,000, range; ¥ 700-123,000), 泌尿器科保険 受診療費（自己負担分）の平均土標準偏差は， ¥6,765 $\pm 11,327$ (median; $¥ 2,300$, range; $¥ 220-70,000$ ) で CAM 負担費用は, 泌尿器科保険受診療費（自己負担分）ょり も高額であった（paired-t test おょび Wilcoxon's test; $\mathrm{p}<0.0001$ ).

\section{CAM 利用による自覚効果}

CAM 利用者に対して，CAM 利用による効果の自覚を 質問したところ，「効果あり」と答えた人が，33名であっ た，その理由として，主だったものは，「体調が良くなっ た」，「症状がよくなった」などであった．

逆に，不都合があったかといら質問に対して，3 名が 「不都合あり」と回答した，その内訳は「肝臓の機能が悪 くなったので開業医に相談したら原因はわからないが止 めるように言われた」,「高額である」,「症状が改善しな かった」であった。

\section{CAM 利用の申告または質問}

CAM 利用に対する医療従事者への申告状況を質問し
たところ「申告有り」と回答した患者は，16名（15.8\%） であり, その内訳は医師への相談 13 名, 看護師への相談 3名であった．医療従事者に相談しない理由は，「相談す ることだとは思わなかった」，「食品なので相談するもの だと思わない」,「信頼していないと思われたら困る」,「家 族がす寸めるので自分で選択したわけではない」，「気軽 に飲んでいるのでいつでもやめられる」,「気休めであ る」，「体に良いと思っている」などであった。

逆に，「他の病院で，CAM 利用に関して質問があった か」に関しては，「有り」と回答した患者は，0名であっ た.さらに, 医療従事者に求める CAM の情報提供の具体 的内容に関して質問したところ「お金をかけているので最 新の情報が欲しい」,「がんが悪いものだという心の不安の ために飲んでいる」,「気休めだが効果があるのか情報が注 しい」，「内服している薬で利用しているものとあわないも のがあれば教えて欲しい」,「医学的・科学的根拠があれば 継続して続けることができる」,「病院も治療とは無関係と 思わず利用しているものに対してわかる範囲で関心を もって評価してもらいたい」,「栄養土や薬剤師に自分にあ ら栄養補助食品について相談したい」などの回答があっ た.

\section{CAM 利用と診療の満足度}

CAM 利用の満足度は，とて子満足 16 名，やや満足 61 名, やや不満足 10 名, 不満足 3 名, 不明 11 名であった. 診療の満足度は, とても満足 28 名, やや満足 56 名, やや 不満足 6 名, 不満足 0 名, 不明 11 名であった.

\section{CAM 利用における情報提供者}

情報提供者は，「自分で選択した」48名，「家族にす寸 められた」28名，「友人にす寸められた」14名，不明 11 名 であった．「自分で選択した」の主な情報源は，雑誌・新 聞，TV，インターネット，ラジオ，薬局などであった.

\section{考 察}

\section{CAM を併用する患者の背景}

CAM の利用には，医療費の高騰による国民医療費の 国庫負担削減対策，慢性疾患の増加と新しい感染症，侵 襲を伴ら治療など西洋医学で力の及ばない病気や不定愁 訴，健康への意識の向上などがある10) と言われており， 社会背景の変化が影響していると言える.

今回, 泌尿器科疾患を有する患者で, CAM 利用者は 
101 名（30.5\%）であった．良性疾患より悪性疾患の方が 利用率が高い傾向を示したが，泌尿器科疾患では疾患に 関わらず，約 3 割の患者が CAM を利用することが明ら かとなった。 これは国内の兵頭ら 3 とょる癌患者を対象 にした先行研究の利用率（約45\%）ょりも低いものの, 前立腺癌患者を対象にした調査報告とほ泳同等の利用率 であった。このことより, 癌の種類や発生部位または, 疾患の良性悪性の違いによる利用率の違いが有ることが 推測された．更に，今回の調查で複数の CAM を利用す る患者がいることも明らかとなり，現在のところ CAM は単独でも情報が不明瞭・不正確な子のが多く, 相互作 用となると把握は増々困難になっており，医療従事者と して決して見過ごす事ができない患者背景があると考兄 られた。

CAM 利用の目的は，がんの再発予防，免疫力の向上 などが主であった：Lippert ${ }^{11)} ら の$ 報告では，前立腺癌患 者の CAM 利用率に関して，癌の悪性度が高い患者ほぞ CAM 利用率が上がり，その理由として，癌患者が，自 分の疾患の告知を受けた際「自ら疾患をコントロールし ようとする気持ちを高めるため，もしくは，自分の精神 的苦悩・悲嘆を隠すため」に利用率が上昇するのではと 推測している. 一方，今回の調査結果で，「現在受けてい る診療についての満足度」を質問したところ,「やや不満 足」と回答した患者は，6名と少なく，また，診療の満 足度と CAM の利用に関連性は認められなかったことか ら, 現在受けている西洋医学の診療に, さらに補足する 医療を患者は自ら求めている現状があると考えられた。

CAM 利用開始時期は，治療前，治療中の患者もいる が, 入院を契機に利用を始める患者が多い傾向を認めた. これは，入院により自己の健康を考える行動のひとつと して CAM 利用といら結論に至った実態があると考えら れた．しかし，その一方で，約5割の患者は，「家族」「「友 人」から勧められたことを契機にCAMの利用を始めたと いら結果より, 患者の疾患・治療に対する周囲の反応と して CAM の利用を開始した背景も推測される。した がって，それ年れの疾患の治療経過中に，患者本人の心 理反応を把握することも重要であるが，患者の「家族」, 「友人」を含めた対応も求められていると思われる.

CAM 利用項目が多かった健康食品に着目すると，そ のほとんどが，厚生労働省が認可する保健機能食品（栄 養機能食品, 特定保健用食品）以外の効果や安全性が確 認されていないいわゆる健康食品であった。医療用医薬 品と健康食品で相互作用があるものも近年指摘されてお り ${ }^{13)}$ ，治療を受ける患者が不利益を受ける危険性が推測 される. 現在, CAM の情報のデータベース化も進めら れており，徐々にではあるが CAM に関する最新の情報
の整理や身体への有害作用の有無への情報提供は，可能 になってきている，米国では，栄養補助食品に関する法 律を制定する目的で 1994 年米国栄養補助食品・健康・教 育法を制定 ${ }^{14)}$ しており，消費者の健康維持増進と同時に 危機回避の要因も含んでいるとしている。，一方，日本で は, 1991 年に特定保健用食品制度, 2001 年に栄養機能食 品制度 ${ }^{15)}$ がスタートしており，国として法的な規制がで きつつある社会背景があり，今後，CAM の利用による 危険を患者から回避させる一助になると思われる。

\section{CAM に費やす費用}

泌尿器科で治療に費やす診療費と CAM に費やす費用 では，診療費よりCAM 利用費の方が高かった結果より， 診療費と CAM を併用することで経済的負担が患者には あると考兄られた。しかし，今回の聞き取り調查におい て患者から経済的な不安の訴えはなかった。これは，費 用への負担感よりも，西洋医学を信頼しつつ，医学では ぞうにもならない症状や不安について何らかの CAM で 補いたい，自然治癒力を高めたいといら思いがあると考 える．また，自分で体に良いものを選択しているという 意識が心の支えに影響していることも考えられる。

\section{CAM 利用者に対する医療従事者の役割と課題}

\subsection{CAM 利用者の申告状況}

CAM 利用について医師や看護師に申告した対象は 16 名（15.8\%）と少なく，特に看護師に相談した患者は 3

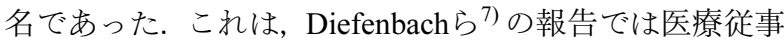
者への申告が $51 \%$ であり，これと比較しても少ない申告 であるといえる．医療従事者に相談しなかった患者の理 由として「相談することだとは思わなかった」，「質問さ れなかった」などの回答であり，今後の看護のあり方に ついて，課題があると考兄られた，さらに，病院を受診 する3〜5 割の患者が，CAMを利用しているという社会 背景を考兄ると，医療従事者が，診療と CAM を併用す ることによる治療と身体への影響について必要な情報を 収集したり，提供したりすることが必要であると考える。 また，患者にCAM の利用に関して質問された際，医療 従事者が「知らない」「見守る」と答えることでは済まさ れなくなってきていると言える。

今西 ${ }^{12)}$ は，これらの点を踏まえ「患者の人権意識が芽 生え, 患者自身が治療法を選ぶ権利のあることに気づき, 西洋医学だけでなく，さまざまな療法を求めるように なってきた，その結果，患者の意志で，補完・代替医療 を選ぶ場面も増えてきている。それに伴い，医師や看護 
職，その他の医療従事者も補完・代替療法について情報 を得て打く必要が出てきたのである」と述べて拈り，医 療従事者に抢汀る CAM についての知識向上が求められ ている点を指摘している.

\section{$3.2 \mathrm{CAM}$ 利用者に対する医療従事者の役割}

兵頭ら 9)の腫瘍医 753 例を対象にした調査に抢いて, 「信頼できる情報が少ないため患者に助言することが困 難である」という臨床では対応が困難な現状を報告して おり，医師でさえ，CAM に対する適切な対応の難しさ があると推察される。CAM に関する医療従事者の対応 については，蒲原は「医師は，患者が CAMを利用して いるかどうかも含めて問診する責務がある4」」と述べて いる，また，日野原 ${ }^{16)}$ は「本来，医療は治りたいという 患者の願望や努力を医療者が援助する行為ともい光, CAM を学ぶ意義は大きい」と述べている。また，医療 者の行動には否定排除型，消極的受容型，積極的受容型 のタイプがあるとしている，我々医療従事者は，患者が 実行している行為に対して，主に見守る態度であり，積 極的に助言できてお拈らず，消極的受容型であったと考光 る. 今回の調査を踏まえ，患者が CAM に関心をもつ事 実を受け止め，医療の選択肢が増えている社会背景を考 えると, 医療従事者がCAMの知識を深めることも重要で あると考える。しかし，日本では CAM の教育や研修の 場が少なく，学ぶ場を見い出す事も課題のひとつである と思われた。

\section{$3.3 \mathrm{CAM}$ 利用者に対する看護師の役割への示唆}

吹田 ${ }^{17)}$ の看護師 1154 例（有効回答率 64.4\%）を対 象にした調査で，CAMを取り入れているがん患者に対 する役割として,「看護独自の介入方法を積極的に取り入 れていく」，「不利益から患者，家族を擁護する」「代替的 治療の知識・情報を提供する」といった「積極的受容型」 の役割を回答したものは少なかったと報告しており、そ の背景として CAM に扔ける看護師に必要な知識や技術 が明らかになっていないことが指摘されて和り，今後の 課題であると思わ水る。

以上より，今後，医療従事者が CAM の情報を得るこ とは重要な責務であるが，どのように情報を得るのかが 課題であると思われる。しかし，CAM の情報を臨床現 場で活用するためには, 従来の西洋医学の知識に加光, 栄養学, 食品と薬物との相互作用に関わる薬物代謝学, 運動生理学等に関する内容も含まれるため, 看護師が単 独で情報を整理・活用することは，情報があまりにも多 く限界がある。よって，看護師の役割には，1）CAMへ の知識を深めること，2）CAM 利用の有無を，患者から
積極的に情報を得ること，3）患者が CAM を利用してい る場合は利用に対する患者心理を受け止めること，4）科 学的に検証されている情報をもとに相互作用と有害事象 について理解すること，5）治療と CAM の情報を整理 し，治療佂よび看護計画の指標とするためにも，CAM の 専門家や栄養士，薬剤師，医師を含めた他職種と連携し 協働を図り，患者に不利益がないか，可能な限り検証す ることが今後の課題であると示唆された.

\section{4. 研究の限界}

今回，単施設による一診療科の調査であり，地域性等に よる CAM 利用の実態を明確にするまでには至っていな い，また，大学病院という特殊性も，今回の聞き取り調査 にバイアスを加えた可能性もある。 今後は，対象者を増や し，地域性や診療科の特性を明らかにすることを目的に検 討を重ねたい。

\section{5. 結論}

今回の研究で，医療従事者が CAM の情報を得ること は重要な責務であり，今後どのように情報を得るのかが 課題と思われた。また治療と同時にCAM を併用寸る患 者の看護には，CAM を利用する患者心理と科学的に検 証されている情報を整理し，更に，生活指導の指標とす るためにも，CAM の専門家や栄養士，薬剤師など他職 種との連携が必要であることが示唆された。

\section{参 考 文 献}

1) 鈴木信孝編著.「適切な代替医療」選択のポイント. 第 1 版. 東京. 日本医療情報出版. 2001: 4.

2) 池内隆夫. 代替医療と泌尿器科疾患. 臨床と薬物治療. 2003 ; 22(6): 550-553.

3）奈良林至. がんに対する補完・代替療法の現状と乞の評価. 緩和医療学. 2003; 5(3): 220-228.

4) 蒲原聖可著. 代替医療. 東京. 中公新書. 2002: 26-35.

5) 山本龍隆，吉田勝美. 聖マリアンナ医科大学病院に打ける 入院患者の代替医療利用状況調査, 日本衛生学雑誌. 2002 ; 57(1): 226

6) 兵頭一之介. 我が国に打けるがんの代替療法に関する研究. 厚生労衝省がん研究助成金に上る研究報告集. 2001; 474478.

7) Diefenbach MA, Hamrick N, Uzzo R, et al. Clinical, demographic and phychosocial complementary and alternative medicin use by men diagnosed with localized prostate cancer. J Urol 2003; 170(1): 166-169. 
8) Yoshimura K, Ichioka K, Terada N, et al. Use of complementary and alternative medicine by patients with localized prostate carcinoma: study at a single institute in Japan. Int J Clin Oncol 2003; 8(1): 26-30.

9) Hyodo I, Eguchi K, Nishina T, et al. Perceptions and attitudes of clinical oncologistis on complementary and alternative medicine: A nationwide survey in Japan. Cancer 2003; 97(11): 2861-2868.

10) 蒲原聖可著. 代替医療. 東京. 中公新書. 2002: 1-6.

11) Lippert MC, McClain R, Boyd JC, et al. Alternative medicine use in patients with localized prostate carcinoma treated with curative intent. Cancer 1999; 86(12): 2642-2648.
12) 今西二郎. 補完・代替医療とは. 緩和医療学. 2003; 15(3): 216 .

13) 徳山尚吾. 医薬品とサプリメントの相互作用一リスク回避 に向けて一。臨床と薬物治療. 2003; 22(6): 600-604.

14）奥田拓道. 健康 - 栄養食品辞典. 東京.（株）東洋医学舎. 1998: 41.

15) http://www.mhlw.go.jp/

16) 日野原重明, 井村裕夫 (監修)。看護のための最新医学講座 第 33 巻alternative medicine. 東京. 中山書店. 2002: 2-6.

17) 吹田夕起子, 出貝裕子, 鳴井ひろみら. がん患者の代替的 治療に対する看護職者の認識. 日本がん看護学会誌. 2004; 18: 167.

\title{
ABSTRACT \\ Prevalence of Complementary and Alternative Medicine Use in Ambulatory Patients with Urologic Disorders
}

\author{
Akiko MARUTANI $^{1}$, Sachie MATUKI ${ }^{1}$, Rie HATTA ${ }^{1}$, Yoshie SAITO $^{1}$, Tae HASHIMOTO ${ }^{1}$, Kazumi MIZUNO $^{1}$, \\ Hiromi TAKEUCHI ${ }^{1}$, Shizue TOMITA ${ }^{1}$, Satoshi $\mathrm{OHNO}^{2}$, Kazuto KOMATSU $^{3}$, Mikio NAMIKI ${ }^{3}$ \\ ${ }^{1}$ Kanazawa University Hospital \\ ${ }^{2}$ Department of Complementary and Alternative Medicine, Kanazawa University \\ ${ }^{3}$ Department of Urology, Kanazawa University Hospital
}

Objective: The prevalence of complementary and alternative medicine (CAM) in patients with various urologic disorders is unknown. We conducted the survey to determine the prevalence of CAM use in ambulatory patients.

Methods: We distributed questionnaires to 331 ambulatory patients with various urologic disorders in our department from March 10 to $31,2004$.

Results: One in third (30.5\%) patients reported the use of at least one CAM. Patient age and gender were not associated with the frequency of the use of CAM. Although not statistically significant, patients with malignant disease showed a higher frequency of CAM use compared with patients with benign disease; $36.2 \%$ vs $27.0 \%, P=0.08$. Among the CAM users, only 16 patients $(15.8 \%)$ informed health care staff of their CAM use.

Conclusion: This result shows the current situation of CAM use in patients with urologic disorders. Because of the high prevalence, health care professionals should ask about patients' use of CAM.

Key words: urologic disease, complementary and alternative medicine, nursing 